\title{
Bullying and cyberbullying: two forms of violence in schools
}

\author{
$M^{a}$ Paz Prendes Espinosa (1) \\ University of Murcia, Spain \{pazprend@um.es\} \\ Received on 29 November 2017; revised on 2 December 2017; accepted on 4 December 2017; published on 15 January 2018
}

\section{$\dot{\sim}$ This volume is dedicated to the memory of Professor Ana Isabel Vázquez $\rightarrow$}

Journal of New Approaches in Educational Research (NAER) presents this special issue focused on bullying and cyberbullying as forms of school violence which have become a focus of interest and a cause of concern for all those of us who develop our professional activity in the field of education. Our journal had already included works about these matters before, such as the one authored by Grau, García, and López (2015).

Even though bullying between schoolchildren is probably as old as the school itself, it was not until the 1970s that Olweus, a Norwegian psychologist, placed the scientific emphasis and attention on this issue. Indeed, he undertook the earliest research works and published the first reports which alarmed the educational community about the importance of the psychological effects that these situations cause on minors. It was him that paved the way for us to recognize the actual relevance of school bullying as a form of violence which may eventually have serious consequences for the life and personal development of the minors concerned. And last but not least, Olweus also pioneered the design of intervention plans based on the educational center's work at an organizational level, both in the classroom context and on an individual basis.'

According to Olweus (1999, p. 10), bullying takes place when a person is exposed, "repeatedly and over a long period of time, to negative actions [...], and when someone deliberately causes, or tries to cause, harm or discomfort to another person." Bullying is a form of violence, and violence "in the school context constitutes a reality that deprives millions of children and youngsters of the fundamental human right to education every day." Hence why UNESCO raises the need to build learning environments which are "safe, non-violent, inclusive and effective for everyone" (UNESCO, without date) and bullying has become one of the most outstanding topics in educational research, as well as in school intervention, during the last few years.

The European Commission has also shown its concern about the problem of school bullying in recent times, financing numerous international projects and collaboration networks aimed at fighting against this phenomenon. Amongst the multiple initiatives, a special mention must be made of the report written by Downes and Cefai (2016) on the prevention of bullying and violence in schools. These authors claim that school bullying is likely to affect students' physical and mental health, recognizing that it occurs for a variety of reasons and in all sorts of situations. It is worth highlighting that the statistics about school bullying in Europe show some countries with school bullying rates above $20 \%$ and $30 \%$-even though our rates in Spain are situated below $10 \%$. The most serious situations arise during the 11-to-15-year age bracket.

Despite being undoubtedly worrying, it must be emphasized that the data for Spain with regard to cyberbullying, and compared to other countries, are low too. An interesting report by Muñoz (2015) collects the findings obtained from a research survey performed with more than 5,000 youngsters in 11 European countries, and it is estimated that $8 \%$ of under- 18 s have undergone cyberbullying situations in Spain, once again well below other countries. And over $71 \%$ of those Spanish students under the age of 18 tell their parents, which reveals the importance of families when it comes to detecting situations of school violence. The same paper highlights the fact that "Spain has one of the world's lowest rates of aggressions through digital media and social networks, and it is one of the countries with a higher degree of awareness about the need to report this phenomenon to the corresponding authorities when it arises."

School bullying -regardless of whether it happens face to face or via cyberbullying - needs preventive, diagnostic, and therapeutic actions, which requires the collaboration of all the centers, families, and agents involved in the education of minors. The importance of institutions and educational policies as drivers of training programs, initiatives, and schemes meant to achieve the highest possible reduction of the incidents which still take place in Spain must not be forgotten either.

The paper authored by Downes, Nairz-Wirth, and Rusinaité (2017) identifies the following measures, amongst others, as being essential in the action against bullying: the promotion of joint policy systems at different levels to build integrating educational centers; organizational and curricular measures in centers; promoting a suitable climate inside classrooms as well as in extra-curricular activities; encouraging social participation; training teachers in competences to meet diversity; fostering professional networks of teachers, along with the exchange of experiences and resources; developing leadership skills within management teams to work along these lines; dealing with these problems from multidisciplinary and cooperative perspectives; providing support for prevention; giving assistance to students with special educational needs; achieving the involvement of families and developing meeting spaces for them in schools; building a social community involved in the life of school centers; and designing structural and political measures suited to this problem.

The same level of concern clearly exists in Spain, as shown by the fact that the Ministry of Education, Culture, and Sport has a remarkable range of resources and reports about both bull-

\footnotetext{
i At http://www.olweusinternational.no
} 
yingi $^{\mathrm{ii}}$ and cyberbullying iii at its disposal. Amongst these resources stands out the report by Orjuela, Cabrera, Calmaestra, Mora, and Ortega (2014) which, in addition to analyzing the situation in Spain, suggests prevention and action measures, additionally introducing the legal aspects of this problem which can under no circumstances be ignored.

Cyberbullying is closely linked to the growing penetration of ICTs at increasingly young ages. The press often echoes cyberbullying incidents, and this undoubtedly constitutes a reason for concern, not only at a social level but also from a scientific point of view, as attested by the objective data of the increased appearance of publications dedicated to this topic during the last ten years.

All these reasons explain why this issue of NAER includes a special section about bullying and cyberbullying for which four papers were selected after the corresponding blind review. The first one of them (authored by M. Foody and M. Samara) addresses the problem of bullying from the perspective of mental health and psychology professionals, taking their analysis as a reference framework to suggest measures revolving on mindfulness techniques used in school intervention programs.

González Calatayud offers a quantitative research undertaken in the Murcia Autonomous Region, where a questionnaire was used to study the phenomenon of cyberbullying between compulsory secondary education students. This paper analyzes the data for victims, obtaining very high percentages, since more than $49 \%$ of students claim to have felt as victims in bullying incidents on some occasion. Such a high percentage seems striking, since it might be interpreted in the light of what students perceive as 'bullying,' as opposed to what can be regarded as such by experts.

Murphy, Tubritt, and O'Higgins add another hugely relevant dimension: teacher training. They present a case study carried out in Ireland and focused on analyzing the degree of empathy and preparedness of teachers at post-primary education levels when it comes to tackling bullying situations. Their data prove the importance of empathy as a resource that teachers have at their disposal to create a positive climate in the classroom which can help avoid bullying and cyberbullying.

And the last contribution to this special issue on bullying and cyberbullying comes from R. Sittichai, who takes us the Asian continent and completes this monograph with a research work developed in Thailand. A survey performed with a sample of over 1,000 cases corresponding to 12-to-18-year-old students serves to focus on the profile of victims, once again insisting on the importance of a trust-based relationship with parents and teachers to tell them what may be happening in the coexistence of youngsters with their peers. It matches the data supplied by González Calatayud when highlighting the differences associated with respondents' gender.

We thank NAER's editorial team for the opportunity to coordinate this special issue focused on such an unquestionably relevant and current topic. It is our conviction that these works will be of great theoretical and practical interest for all those of us who deal with this problem and its possible solutions, not only in the field of detection and prevention but also in the context of intervention and treatment. Hopefully these contributions will serve as reminders of the importance for a joint action to be taken from the various institutions and specialists, as well as of the need to work on the basis of prevention and therapy, so that the number

ii At https://www.mecd.gob.es/educacion/mc/convivencia-escolar/recursos/materiales-otros-recursos/acoso-escolar.html

iii At https://www.mecd.gob.es/educacion/mc/convivencia-escolar/recursos/materiales-otros-recursos/ciberacoso.html of cases can diminish more and more within a society educated in respect and equity.

$\mathrm{M}^{\mathrm{a}}$ Paz Prendes Espinosa University of Murcia

\section{REFERENCES}

Downes, P., \& Cefai, C. (2016). How to Prevent and Tackle Bullying and School Violence: Evidence and Practices for Strategies for Inclusive and Safe Schools, NESET II report. Luxembourg: Publications Office of the European Union.

Downes, P., Nairz-Wirth, E., \& Rusinaitè, V. (2017). Structural Indicators for Inclusive Systems in and around Schools, NESET II report. Luxembourg: Publications Office of the European Union.

Grau, R., García-Braga, L., \& López-Martín, R. (2015). Hacia la transformación de la escuela. Valoración de un programa de convivencia a partir de la voz del alumnado y del profesorado. New Aprroaches in Educational Research, 5(2).

Olweus, D. (1999). Sweden. In P. Smith, Y. Morita, J. Junger-Tas, D. Olweus, R. Catalano, \& P. Slee (Eds.), The Nature of School Bullying: A cross-national Perspective (pp. 7-27). London: Routledge.

Orjuela, L., Cabrera, B., Calmaestra, J., Mora, J. y Ortega, R. (2014). Acoso escolar y ciberacoso: propuestas para la acción. Madrid: Ministerio de Sanidad, Asuntos Sociales e Igualdad. Retrieved from https:/www.savethechildren.es/sites/ default/files/imce/docs/acoso_escolar_y_ciberacoso_informe_vok_-_05.14.pdf

UNESCO. Acoso y violencia escolar. Retrieved from https://es.unesco.org/themes/ acoso-violencia-escolar

Muñoz, R. (2015). Los menores españoles son los que menos cieberacoso sufren. El País. Recuperado de https://elpais.com/tecnologia/2015/09/22/actualidad/1442940249_520165.html

How to cite this article: Prendes, M. P. (2017). Bullying and cyberbullying: two forms of violence in schools. Journal of New Approaches in Educational Research, 7(1), 1-2. doi: 10.7821/naer.2018.1274 